\title{
KUALITAS PRODUK DAN KUALITAS LAYANAN TERHADAP KEPUASAN DAN LOYALITAS NASABAH
}

\author{
Kharisma Nawang Sigit ${ }^{1}$, Euis Soliha ${ }^{2}$ \\ ${ }^{1}$ Departemen Magister Manajemen Program Pascasarjana \\ ${ }^{2}$ Departemen Manajemen Fakultas Ekonomika dan Bisnis \\ Universitas Stikubank Semarang \\ Jl. Kendeng V Bendan Ngisor Semarang, 50233, Indonesia
}

\begin{abstract}
Keywords:
Customer Loyalty, Customer Satisfaction, Quality of Product, Quality of Service
\end{abstract}

JEL Classification: G21, M21, M31

Kata Kunci: Kualitas Produk, Kualitas Layanan, Kepuasan Nasabah, Loyalitas Nasabah.

\begin{abstract}
This study described the effect of product quality and service quality on sustomer satisfaction and loyalty. The population in this study was the customers of Kredit Usaha Rakyat at BRI Warungasem. The sampling method used in this research was purposive sampling. The samples in this study were 100 customers in People's Business Credit (Kredit Usaha Rakyat) BRI Batang Branch Unit Warungasem who had already taken at least two time KUR credits. The instrument of answers measurement used was a Likert scale 1-7 alternative answers. Testing instrument used was validity and reliability, and testing the model used was the coefficient of determination and F test (goodness of fit). Testing the hypothesis in this study used t test. Variables used in the study were product quality, service quality, customer satisfaction and loyalty. The results showed that there was the effect on the product quality and customer satisfaction. Service quality affected the customer satisfaction. Product quality affect the customer loyalty. The quality of service had an effect on customer loyalty. Customer satisfaction had an effect on customer loyalty.
\end{abstract}

\begin{abstract}
Abstrak
Penelitian ini menjelaskan pengaruh kualitas produk dan kualitas layanan terhadap kepuasan nasabah dan loyalitas. Populasi pada penelitian ini adalah nasabah Kredit Usaha Rakyat BRI Unit Warungasem. Metode pengambilan sampel yang digunakan dalam penelitian ini adalah purposive sampling. Sampel dalam penelitian ini adalah 100 nasabah Kredit Usaha Rakyat di BRI Cabang Batang Unit Warungasem yang sudah mengambil minimal dua kali kredit KUR.Pengukuran jawaban instrumen menggunakan skala likert 1-7alternatif jawaban. Pengujian instrumen menggunakan validitas dan reliabilitas, pengujian model menggunakan koefisien determinasi, dan uji $\mathrm{F}$ (goodness of fit). Pengujian hipotesis dalam penelitian ini menggunakan uji t. Variabel yang digunakan dalam penelitian yaitu Kualitas Produk, kualitas layanan, kepuasan dan loyalitas nasabah. Hasil penelitian menunjukkan bahwa kualitas produk berpengaruh terhadap kepuasan Nasabah.Kualitas layanan berpengaruh terhadap kepuasan Nasabah. Kualitas produk berpengaruh terhadap loyalitas Nasabah.Kualitas layanan berpengaruh terhadap loyalitas Nasabah.Kepuasan berpengaruh terhadap loyalitas Nasabah.
\end{abstract}


Bank Rakyat Indonesia (BRI) sebagai salah satu pelaku usaha dalam industri perbankan tidak lepas dari fenomena perubahan yang timbul dari intensitas persaingan untuk mendapatkan hati pelanggan (nasabah) mereka. Saat ini perilaku nasabah bank di Indonesia makin tidak mudah untuk ditebak, ada nasabah yang menginginkan suku bunga yang rendah (contoh pinjaman) atau suku bunga yang tinggi (contoh tabungan, giro dan deposito), biaya administrasi yang rendah dan ada pula nasabah yang menginginkan transaksi keuangan yang cepat, efisien, nyaman dan mudah dalam pengaksesannya, kapanpun, dan dimanapun, selain itu juga program dan produk yang ditawarkan. Image (citra) bank salah satu diantara dapat terjadi karena adanya kualitas layanan yang baik dan memuaskan nasabah yangakan berdampak pada loyalitas. Sinergi atas layanan, citra bank yang baik berdampak pada kepuasan nasabah. Selanjutnya kepuasan nasabah pada gilirannya akan dapat menciptakan hubungan berlanjut antara nasabah dengan bank dalam wujud adanya transaksi berulang atau loyalitas (Sumadi \& Soliha, 2015).

Secara teoritis merujuk pada hasil penelitian terdahulu bahwa kepuasan nasabah dan loyalitas nasabah dipercaya mampu memberikan dampak yang positif dan pengaruh yang signifikan bagi kelangsungan bank baik dalam jangka pendek maupun untuk jangka panjang (Liu \& Wu, 2007; Dimitriades, 2006).

Menurut Aidil (2014) KUR merupakan program pemberian kredit/pembiayaan dengan nilai dibawah 5 (lima) juta rupiah dengan pola penjaminan oleh pemerintah dengan besarnya coverage penjaminan maksimal 70\% dari plafon kredit. Lembaga penjaminnya adalah PT. Jamkrindo dan PT Askrindo. Tujuan program KUR adalah mengakselerasi pengembangan kegiatan perekonomian di sektor riil dalam rangka penanggulangan dan pengentasan kemiskinan serta perluasan kesempatan kerja. Sasaran program KUR adalah kelom- pok masyarakat yang telah dilatih dan ditingkatkan keberdayaan serta kemandiriannya pada kluster program sebelumnya. Harapannya agar kelompok masyarakat tersebut mampu untuk memanfaatkan skema pendanaan yang berasal dari lembaga keuangan formal seperti bank, koperasi, BRI dan sebagainya. Dilihat dari sisi kelembagaan, maka sasaran KUR adalah UMKMK (Usaha Mikro, Kecil, Menengah dan Koperasi). Sektor usaha yang diperbolehkan untuk memperoleh KUR adalah semua sektor usaha produktif.

Begitu juga dengan Bank Rakyat Indonesia (BRI) dalam pengelolaan usaha pelayanan kredit selalu memperhitungkan sifat kehati-hatian dimana bank selalu memperhatikan tingkat keberhasilan pihak debitur dalam mengelola usaha yang dibiayai oleh fasilitas kredit usaha yang diberikan oleh BRI. Salah satu program unggulan dalam rangka membantu para nasabah untuk penyediaan modal usaha adalah Kredit Usaha Rakyat (KUR) KUR Mikro yang membiayai pinjaman untuk usaha pertanian, pertambangan, perdagangan dan restoran, pengangkutan, jasa-jasa dunia usaha, dan jasa-jasa sosial dan lain-lain (Halid dkk., 2014).

Pihak bank BRI telah mempersiapkan tata kelola kredit dengan menyusun standar operasional prosedural sebagai langkah-langkah yang harus dilakukan oleh internal bank dalam menangani setiap permohonan pembiayaan yang diajukan oleh pihak calon debitur selain itu dalam hal teknologi, BRI selalu memperbarui dan mengembangkan peralatan yang sudah ada, contohnya BRI selalu menambah jaringan ATM bahkan saat ini BRI mempunyai satelit sendiri, hal ini dilakukan untuk mempermudah, mempercepat transaksi nasabah setia BRI. Persaingan yang dihadapi oleh BRI bukan saja sesama BRI tetapi juga bersaing dengan bank umum yang mempunyai kemampuan SDM, teknologi dan modal yang besar jika dibandingkandengan BRI. 


\section{Kualitas Produk dan Kualitas Layanan terhadap Kepuasan dan Loyalitas Nasabah}

Euis Soliha \& Kharisma Nawang Sigit

\section{Kualitas Produk}

Kualitas produk adalah keadaan fisik, fungsi dan sifat produk bersangkutan yang dapat memenuhi selera dan kebutuhan konsumen dengan memuaskan sesuai nilai uang yang dikeluarkan (Prawirosentono, 2004).Kualitas produk (product quality) adalah kemampuan suatu produk untuk melaksanakan fungsinya, meliputi daya tahan, keandalan, ketepatan, kemudahan operasi, dan perbaikan serta atribut bernilai lainnya (Kotler \& Keller, 2013). Kualitas merupakan salah satu alat utama untuk positioning menetapkan posisi bagi pemasar.Kualitas produk mempunyai dua dimensi yaitu tingkat dan konsistensi.Kualitas yang baik menurut produsen adalah apabila produk yang dihasilkan olehperusahaan telah sesuai dengan spesifikasi yang telah ditentukan oleh perusahaan. Sedangkan kualitas yang jelek adalah apabila produk yang dihasilkan tidak sesuaidengan spesifikasi standar yang telah ditentukan serta menghasilkan produk rusak. Kotler \& Armstrong (2012) mendefinisikan kualitas produk adalah kemampuan sebuah produk dalam memperagakan fungsinya, hal itu termasuk keseluruhan durabilitas, reliabilitas, ketepatan, kemudahan pengoperasian, dan reparasi produk juga atribut.

\section{Kualitas Layanan}

Kualitas (quality) adalah totalitas fitur dan karakteristik produk atau jasa yang bergantung pada kemampuannya untuk memuaskan kebutuhan yang dinyatakan atau tersirat (Kotler \& Keller, 2009). Ini jelas merupakan definisi yang berpusat pada nasabah. Perusahaan yang memuaskan sebagian besar kebutuhan nasabahnya sepanjang waktu disebut perusahaan berkualitas, tapi harus dibedakan antara kesesuaian kualitas dan kinerja (atau tingkat) kualitas (Kotler \& Keller, 2009).

Gronroos (1988) mendefinisikan kualitas pelayanan sebagai hasil persepsi dari perbandingan antara harapan pelanggan dengan kinerja aktual pelayanan. Dengan kata lain ada dua faktor utama yang memengaruhi kualitas jasa, yaitu expected service (pengalaman yang diharapkan) dan perceived service (pelayanan yang diterima). Sementara itu kualitas total suatu jasa terdiri dari 3 komponen utama, yaitu: technical quality (terdiri dari: search quality, experience quality, credence quality), functional quality, dan coorporate image.

\section{Kepuasan Pelanggan}

Kepuasan pelanggan (customer satisfaction) adalah suatu tingkatan dimana perkiraan kinerja produk sesuai dengan harapan pembeli (Kotler \& Keller, 2013). Kepuasan pelanggan bergantung pada perkiraan kinerja produk dalam memberikan nilai, relatif terhadap harapan pembeli.Jika kinerja produk jauh lebih rendah dari harapan pelanggan, pembeli tidak terpuaskan.Jika kinerja sesuai dengan harapan, pembeli terpuaskan.Jika kinerja melebihi yang diharapkan, pembeli lebih senang. Pelanggan yang merasa puas akan kembali membeli dan akan memberi tahu kepada yang lain tentang pengalaman baik terhadap produk tersebut. Kepuasan merupakan salah satu indikator dalam pengukuran kualitas layanan ditengah persaingan dengan perusahaan lainnya. Boulding et al. (1993) menjelaskan bahwa harapan pelanggan mempunyai peranan penting dalam menentukan kualitas produk (barang dan jasa) dan kepuasan pelanggan karena pada dasarnya terdapat hubungan yang erat antara penentuan kualitas dan kepuasan pelanggan. Dalam mengevaluasinya, pelanggan akan menggunakan harapannya sebagai standar atau acuan. Kepuasan secara langsung akan memengaruhi loyalitas yang pada akhirnya dapat menurunkan biaya operasi serta meningkatkan pendapatan dan profitabilitas perusahaan.

Definisi konsep kepuasan pelanggan yang digunakan dalam penelitian ini adalah tanggapan pelanggan dapat berupa perasaan senang atau kecewa atas perbandingan antara produk yang diterima dengan yang diharapkan sebagai evaluasi 
atau penilaian pelanggan secara keseluruhan terhadap pembelian dan pengalaman penggunaan produk atau jasa tersebut (Taylor \& Baker, 1994).

\section{Loyalitas Pelanggan}

Loyalitas nasabah adalah komitmen yang tinggi untuk membeli kembali suatu produk atau jasa yang disukai di masa mendatang, disamping pengaruh situasi dan usaha pemasar dalam merubah perilaku. Dengan kata lain nasabah akan setia untuk melakukan pembelian ulang secara terusmenerus. Untuk mempertahankan loyalitas nasabah tidak hanya dibutuhkan kepuasan, melainkan lebih dari itu adalah kepercayaan nasabah yang merupakan kunci dari relationship marketing. Adapun definisi loyalitas adalah pembentukan sikap dan pola perilaku seorang konsumen terhadap pembelian dan penggunaan produk hasil dari pengalaman mereka sebelumnya (Griffin, 2005).

Konsumen yang dapat dikategorikan sebagai konsumen yang setia adalah konsumen yang puas dengan produk tertentu sehingga mereka mempunyai antusiasme untuk memperkenalkannya pada siapapun yang mereka kenal. Selanjutnya konsumen yang loyal juga akan menunjukkan kesetiaan mereka dengan membeli produk-produk lainnya dari perusahaan yang sama.

Loyalitas terbentuk dari dua komponen, loyalitas sebagai perilaku yaitu pembelian ulang yang konsisten dan loyalitas sebagai sikap yaitu sikap positif terhadap suatu produk atau produsen (penyedia jasa) ditambah dengan pola pembelian yang konsisten. Berdasarkan hal tersebut, dapat disimpulkan bahwa loyalitas konsumen terhadap suatu produk berhubungan dengan sikap positif yang dimiliki konsumen terhadap produk dengan melakukan pembelian ulang secara konsisten.

Berdasarkan latar belakang tersebut penelitian ini menjelaskan pengaruh kualitas produk dan kualitas layanan terhadap kepuasan nasabah dan loyalitas nasabah Kredit Usaha Rakyat pada Bank BRI Cabang Batang Unit Warungasem.

\section{PENGEMBANGAN HIPOTESIS}

\section{Pengaruh Kualitas Produk terhadap Kepuasan Nasabah.}

Hubungan kualitas produk dengan kepuasan pelanggan tersebut berdasarkan penelitian Munisih \& Soliha (2015) menunjukkan kualitas produk berpengaruh positif dan signifikan terhadap kepuasan pelanggan, dimana kualitas produk yang meningkat maka kepuasan pelanggan juga meningkat. Menurut Lumintang \& Rotinsulu (2015) menjelaskan bahwa kualitas produk mempunyai peran dalam memasarkan suatu organisasi karena berpotensi memengaruhi persepsi dan ekspektasi nasabah tentang barang atau jasa yang ditawarkan serta pada akhirnya memengaruhi kepuasan nasabah dan loyalitas.

Dengan adanya kualitas produk yang baik ini akan memengaruhi kepuasan konsumen. Dalam hal ini untuk kepuasan nasabah juga akan dipengaruhi oleh adanya kualitas produk perbankan yang ditawarkan. Jika nasabah merasakan kualitas produk perbankan semakin bagus maka akan meningkatkan kepuasan nasabah. Berdasarkan teori dan empiris maka hipotesis pertama adalah sebagai berikut:

$\mathbf{H}_{\mathbf{1}}$ : kualitas produk berpengaruh positif terhadap kepuasan nasabah

\section{Pengaruh Kualitas Layanan terhadap Kepuasan Nasabah}

Menurut Parasuraman et al. (1985) terdapat dua faktor utama yang memengaruhi kualitas jasa, yaitu expected service dan perceived service. Apabila jasa yang diterima atau dirasakan (perceived service) sesuai dengan yang diharapkan maka kualitas jasa yang dipersepsikan baik dan memuaskan. Jika pelayanan yang diterima melampaui harapan konsumen, maka kualitas pelayanan dipersepsikan sebagai kualitas pelayanan yang ideal. Sebaliknya jika pelayanan yang diterima lebih rendah dari yang 


\section{Kualitas Produk dan Kualitas Layanan terhadap Kepuasan dan Loyalitas Nasabah}

Euis Soliha \& Kharisma Nawang Sigit

diharapkan, maka kualitas pelayanan dipersepsikan buruk.

Agung \& Soliha (2014) menunjukkan bahwa kualitas layanan berpengaruh terhadap kepuasan. Apabila pelayanan yang diterima atau dirasakan pelanggan sesuai atau bahkan melebihi harapan pelanggan, maka pelayanan tersebut dianggap berkualitas dan memuaskan. Namun, pelayanan yang tidak sesuai atau di bawah harapan, maka pelayanan dianggap tidak berkualitas atau mengecewakan. Yulianti (2013) menunjukkan bahwa kualitas layanan berpengaruh signifikan terhadap kepuasan nasabah Bank Panin. Setiawan (2016) juga menunjukkan hal yang sama pada pengguna layanan mobile banking. Nursiana (2015) juga menunjukkan hal yang sama pada nasabah bank di Jakarta. Oleh karena itu, kualitas layanan yang dirasakan nasabah diprediksi akan meningkatkan kepuasan nasabah, maka hipotesis kedua dirumuskan sebagai berikut:

$\mathbf{H}_{2}$ : kualitas layanan berpengaruh positif terhadap kepuasan nasabah

\section{Pengaruh Kualitas Produk terhadap Loyalitas Nasabah}

Kualitas produk yang baik akan menimbulkan keinginan konsumen atau pelanggan untuk melakukan pembelian ulang. Kepuasan pelanggan merupakan penyebab utama timbulnya loyalitas yang tinggi. Terciptanya kepuasan pelanggan dapat memberikan manfaat, diantaranya hubungan antara perusahaan dengan pelanggannya menjadi harmonis. Hubungan tersebut merupakan dasar yang baik bagi pembelian ulang dan terciptanya loyalitas pelanggan, dan membentuk suatu rekomendasi dari mulut ke mulut (word of mouth) yang menguntungkan bagi perusahaan.

Asosiasi nasabah (klien) yang baik terhadap perusahaan menjadi dasar untuk menumbuhkan loyalitas nasabah.Kecenderungan nasabah lebih didominasi kepada kualitas produk perusahaan di- bandingkan produk yang dihasilkan. Irawan dan Japarianto (2013) menunjukkan bahwa kualitas produk berpengaruh terhadap loyalitas. Kualitas produk yang semakin baik akan menyebabkan nasabah menjadi puas dan senang sehingga nasabah akan loyal. Hipotesis ketiga dirumuskan sebagai berikut:

$\mathbf{H}_{3}$ : kualitas produk berpengaruh positif terhadap loyalitas nasabah

\section{Pengaruh Kualitas Layanan terhadap Loyalitas Nasabah}

Loyalitas nasabah menggambarkan komitmen yang diberikan nasabah untuk menggunakan kembali atas jasa yang diberikan di masa yang akan datang. Hasil penelitian Akbar\& Parves (2009) menunjukkan terdapat hubungan yang positif dan signifikan antara kualitas pelayanan terhadap loyalitas pelanggan. Agung \& Soliha (2014) juga menunjukkan kualitas layanan berpengaruh positif dan signifikan terhadap loyalitas. Setiawan (2016) juga menunjukkan hal yang sama pada pengguna layanan mobile banking.

Penelitian yang dilakukan Aryani \& Rosinta (2010) terdapat pengaruh yang kuat dan positif antara kualitas layanan terhadap loyalitas. Peningkatan kualitas layanan nasabah memberikan kontribusi untuk loyalitas. Oleh karena itu, kualitas layanan yang dirasakan oleh nasabah akan memengaruhi loyalitas nasabah. Jadi, loyalitas nasabah tidak bisa dikesampingkan oleh pihak bank karena hal ini akan memengaruhi profitabilitas. Niat kunjungan kembali nasabah tentunya tidak serta merta dilakukan nasabah tanpa alasan. Atas dasar kualitas yang diatas ekspektasi atau harapan mereka, maka akan membuat komitmen masyarakat untuk berkunjung atau menggunakan jasa layanan bank yang sama. Hipotesis keempat dirumuskan sebagai berikut:

$\mathbf{H}_{4}$ : kualitas layanan berpengaruh positif terhadap loyalitas nasabah 


\section{Pengaruh Kepuasan Nasabah terhadap Loyalitas Nasabah}

Kepuasan nasabah memiliki pengaruh besar dalam menciptakan loyalitas nasabah. Nasabah akan setia atau loyal terhadap suatu produk bila nasabah mendapatkan kepuasan dari produk tersebut. Untuk meningkatkan kepuasan, perusahaan perlu mengatur strategi pemasaran agar nasabah tertarik terhadap layanan yang ditawarkan.

Konsekuensi kepuasan atau ketidakpuasan nasabah sangat krusial bagi kelangsungan hidup dan daya saing perusahaan. Penelitian Agung \& Soliha (2014), Munisih \& Soliha (2015), dan Solechah \& Soliha (2015) menunjukkan bahwa kepuasan pelanggan berpengaruh positif dan signifikan terhadap loyalitas. Penelitian yang dilakukan oleh Hidayat (2009) menyatakan dari hasil penelitian yang dilakukannya di Bank Mandiri bahwa kepuasan nasabah berpengaruh positif terhadap loyalitas nasabah. Setiawan (2016) juga menunjukkan hal yang sama pada pengguna layanan mobile banking.

Emosi positif yang diberikan nasabah setelah menggunakan layanan bank akan menunjukkan kepuasan mereka terhadap layanan bank. Jika nasabah merasa puas dengan layanan KUR bank, maka nasabah akan tetap setia untuk menggunakan jasa layanan pada KUR tersebut di masa yang akan datang. Hipotesis kelima dirumuskan sebagai berikut:

$\mathbf{H}_{5}$ : kepuasan nasabah berpengaruh positif terhadap loyalitas nasabah

\section{METODE}

Populasi dalam penelitian ini adalah nasabah di Bank BRI Cabang Batang Unit Warungasem. Teknik pengambilan sampel yang digunakan dalam penelitian ini adalah purposive sampling, yaitu peneliti menentukan kriteria-kriteria tertentu terhadap sampel yang akan dijadikan obyek penelitian. Adapun kriteria-kriteria sampel adalah: (1) Responden berada pada BRI Unit Warungasem saat penelitian berlangsung. (2) Responden merupakan nasabah pinjaman KUR BRI Unit Warungasem. (3) Responden merupakan nasabah pinjaman KUR BRI Unit Warungasem yang sudah mengambil minimal 2 (dua) kali pinjaman KUR. (4) Responden merupakan nasabah KUR dengan mininmal usia 21 tahun atau kuang dari 21 tahun tapi sudah menikah, dengan alasan usia 21 tahun sudah dewasa. Jumlah nasabah pinjaman KUR Bank BRI cabang Batang Unit Warungasem yang telah menggunakan jasa pinjaman KUR minimal 2 kali pengambilan pinjaman dari jumlah keseluruhan nasabah pinjaman KUR sebanyak 858 nasabah. Berdasarkan perhitungan dengan rumus Slovin dengan batas toleransi 10\% maka diperoleh hasil 89,56. Hal ini menunjukkan sampel minimal adalah 90, sehingga dalam penelitian ini jumlah sampel ditetapkan 100 nasabah.

Metode pengumpulan data yang digunakan dalam penelitian ini adalah dengan menggunakan kuisioner yang terdiri dari sejumlah pernyataan dan pertanyaan tertulis kepada responden tentang kualitas produk, kualitas layanan, kepuasan nasabah dan loyalitas nasabah.Pernyataan-pernyataan dalam kuisioner diukur dengan menggunakan skalalikert 1-7 dimana 1 menunjukkan tingkatan sangat tidak setuju sedangkan tingkatan 7 menunjukkan sangat setuju.

Adapun indikator pada masing-masing variabel yang terdiri indikator kualitas produk, indikator kualitas layanan, indikator kepuasan pelanggan, dan indikator loyalitas nasabah ditunjukkan pada Tabel 1.

Analisis data menggunakan analisis regresi berganda dengan rumus sebagai berikut:

$$
\begin{aligned}
& Y_{1}=a+b_{1} X_{1}+b_{2} X_{2} \\
& Y_{2}=a+b_{1} X_{1}+b_{2} X_{2}+b_{3} Y_{1} \\
& \text { Keterangan : } \\
& Y_{1}=\text { Kepuasan Nasabah } \\
& Y_{2}=\text { Loyalitas Nasabah } \\
& X_{1}=\text { Kualitas Produk } \\
& X_{2}=\text { Kualitas Layanan } \\
& a \quad=\text { konstanta } \\
& b \quad=\text { koefisien regresi }
\end{aligned}
$$


Tabel 1. Indikator Variabel Penelitian

\begin{tabular}{llll}
\hline $\begin{array}{c}\text { Indikator kualitas } \\
\text { produk }\end{array}$ & $\begin{array}{c}\text { Indikator kualitas } \\
\text { layanan }\end{array}$ & $\begin{array}{c}\text { Indikator Kepuasan } \\
\text { Nasabah }\end{array}$ & Indikator Loyalitas Nasabah \\
\hline - Kesesuaian & - Peralatan & - Nasabah senang & - Repeat purchase adalah \\
produk & - Perlengkapan & melakukan pembelian & kesediaan nasabah untuk \\
- Kualitas & - Kebersihan & - Berdasarkan & membeli ulang produk \\
produk dapat & - Penampilan & pengalaman, nasabah & layanan \\
bersaing & Karyawan & puas melakukan & - Retention adalah \\
- Jangka waktu & - Kenyamanan & pembelian & ketahanan nasabah \\
ketahanan & - Keamanan & - Produk sudah memenuhi & terhadap pengaruh yang \\
produk & - Ketepatan & harapan nasabah & negatif mengenai bank \\
Kualitas & waktu & - Secara keseluruhan, & - Referalls adalah \\
keamanan & - Keramahan & nasabah percaya bahwa & kesediaan nasabah untuk \\
menggunakan & & produk tidak & membeli lini produk lain. \\
Produk & & mengecewakan nasabah & \\
& & Nasabah tidak complain & \\
& & terhadap produk & \\
\hline
\end{tabular}

Tabel 2. Validitas Kualitas Produk, Kualitas Layanan, Kepuasan Nasabah dan Loyalitas Nasabah

\begin{tabular}{|c|c|c|c|c|}
\hline Variabel & Item & $\begin{array}{c}\text { Loading Factor } \\
\text { (Component Matrik) }\end{array}$ & Ketetapan & Keterangan \\
\hline \multirow{3}{*}{ Kualitas Produk $\left(\mathrm{X}_{1}\right)$} & $\mathrm{X}_{1.1}$ & 0,846 & \multirow{16}{*}{0,40} & Valid \\
\hline & $\mathrm{X}_{1.2}$ & 0,855 & & Valid \\
\hline & $\mathrm{X}_{1.3}$ & 0,879 & & Valid \\
\hline \multirow{3}{*}{ Kualitas Layanan $\left(X_{2}\right)$} & $\mathrm{X}_{1.4}$ & 0,907 & & Valid \\
\hline & $\mathrm{X}_{2.1}$ & 0,717 & & Valid \\
\hline & $\mathrm{X}_{2.2}$ & 0,581 & & Valid \\
\hline \multirow{5}{*}{ Kepuasan Nasabah $\left(\mathrm{Y}_{1}\right)$} & $\mathrm{X}_{2.3}$ & 0,710 & & Valid \\
\hline & $\mathrm{X}_{2.4}$ & 0,768 & & Valid \\
\hline & $\mathrm{Y}_{1.1}$ & 0,634 & & Valid \\
\hline & $\mathrm{Y}_{1.2}$ & 0,578 & & Valid \\
\hline & $Y_{1.3}$ & 0,678 & & Valid \\
\hline \multirow{5}{*}{ Loyalitas Nasabah $\left(\mathrm{Y}_{2}\right)$} & $\mathrm{Y}_{1.4}$ & 0,736 & & Valid \\
\hline & $\mathrm{Y}_{1.5}$ & 0,601 & & Valid \\
\hline & $\mathrm{Y}_{2.1}$ & 0,906 & & Valid \\
\hline & $\mathrm{Y}_{2.2}$ & 0,919 & & Valid \\
\hline & $Y_{2.3}$ & 0,964 & & Valid \\
\hline
\end{tabular}

\section{HASIL}

\section{Pengujian Instrumen Penelitian}

\section{Uji validitas}

Uji validitas menggunakan analisis faktor Kaiser-Meyer-Olkin Measure of Sampling Adequacy (KMO MSA). Nilai yang dikehendaki harus $>0,50$ untuk dapat dilakukan analisis faktor (Ghozali, 2011), sedangkan indikator dinyatakan valid jika loading factor $>0,4$. Hasil uji validitas ditunjukkan dalam Tabel 2.

Berdasarkan Tabel 2 menunjukkan bahwa pada pengujian validitas untuk masing-masing variabel kualitas produk, kualitas layanan, kepuas- 
an nasabah, dan loyalitas nasabah hasilnya adalah valid.

\section{Uji Reliabilitas}

Uji reliabilitas dalam penelitian ini menggunakan uji statistik Alpha Cronbach $(\alpha)$. Suatu konstruk dinyatakan reliabel jika memberikan nilai Alpha Cronbach >0,60 (Ghozali, 2011).

Berdasarkan Tabel 3 dapat diketahui bahwa masing-masing variabel ternyata diperoleh nilai Alpha Cronbach lebih besar dari nilai standarisasi atau batas yang ditentukan yaitu 0,600. Dengan demikian, hasil uji reliabilitas terhadap keseluruhan variabel adalah reliabel.

\section{Analisis Regresi Berganda}

Hasil analisis regresi berganda ditunjukkan dalam Tabel 4.

Hasil regresi persamaan 1 menunjukkan adjusted $\mathrm{R}^{2}$ sebesar 0,322 berarti bahwa 32,2 \% variasi partisipasi dapat dijelaskan oleh variasi dari kedua variabel independen kualitas produk, kualitas layanan, sedangkan sisanya sebesar $67,8 \%$ dijelaskan oleh sebab-sebab yang lain di luar model. Hasil regresi persamaan 2 menunjukkan adjusted $\mathrm{R}^{2}$ sebesar 0,798 berarti bahwa 79,8 \% variasi partisipasi dapat dijelaskan oleh variasi dari ketiga variabel independen kualitas produk, kualitas layanan dan kepuasan, sedangkan sisanya sebesar 20,2\% dijelaskan oleh sebab-sebab yang lain di luar model.

Tabel 3. Uji Reliabilitas Indikator Variabel

\begin{tabular}{lccc}
\hline \multicolumn{1}{c}{ Variabel } & $\begin{array}{c}\text { Alpha } \\
\text { Cronbach }\end{array}$ & $\begin{array}{c}\text { Nilai } \\
\text { Standarisasi }\end{array}$ & Ket \\
\hline $\begin{array}{l}\text { Kualitas } \\
\text { produk }\end{array}$ & 0,893 & 0,600 & Reliabel \\
$\begin{array}{l}\text { Kualitas } \\
\text { layanan }\end{array}$ & 0,645 & 0,600 & Reliabel \\
$\begin{array}{l}\text { Kepuasan } \\
\text { Loyalitas }\end{array}$ & 0,647 & 0,600 & Reliabel \\
\hline
\end{tabular}

Hasil uji F diperoleh nilai signifikan 0,000 $(\operatorname{sig}<\alpha=0,05)$ hasil ini memperlihatkan bahwa model mampu secara signifikan dalam menjelaskan fenomena sejauh mana variabel kualitas produk,

Tabel 4. Hasil Uji Regresi

\begin{tabular}{|c|c|c|c|c|c|c|}
\hline \multirow{2}{*}{ Model } & \multirow{2}{*}{$\begin{array}{l}\text { Adjusted } \\
\text { R Square }\end{array}$} & \multicolumn{2}{|c|}{ Uji F } & \multicolumn{2}{|c|}{ Uji t } & \multirow[t]{2}{*}{ Keterangan } \\
\hline & & $\mathrm{F}$ & Sign & B & Sign & \\
\hline Persamaan 1 & & & & & & \\
\hline $\begin{array}{l}\text { Kualitas produk dan kualitas } \\
\text { layanan terhadap kepuasan }\end{array}$ & 0,322 & 24,525 & 0,000 & & & \\
\hline $\begin{array}{l}\text { Kualitas produk terhadap } \\
\text { kepuasan }\end{array}$ & & & & 0.378 & 0.000 & Hipotesis diterima \\
\hline $\begin{array}{l}\text { Kualitas layanan terhadap } \\
\text { kepuasan }\end{array}$ & & & & 0.277 & 0.006 & Hipotesis diterima \\
\hline Persamaan 2 & & & & & & \\
\hline $\begin{array}{l}\text { Kualitas produk, kualitas } \\
\text { layanan, kepuasan terhadap } \\
\text { loyalitas }\end{array}$ & 0.798 & 131,107 & 0,000 & & & \\
\hline $\begin{array}{l}\text { Kualitas produk terhadap } \\
\text { loyalitas }\end{array}$ & & & & 0,537 & 0,000 & Hipotesis diterima \\
\hline $\begin{array}{l}\text { Kualitas layanan terhadap } \\
\text { loyalitas }\end{array}$ & & & & 0,333 & 0,000 & Hipotesis diterima \\
\hline Kepuasan terhadap loyalitas & & & & 0,190 & 0,001 & Hipotesis diterima \\
\hline
\end{tabular}




\section{Kualitas Produk dan Kualitas Layanan terhadap Kepuasan dan Loyalitas Nasabah}

Euis Soliha \& Kharisma Nawang Sigit

kualitas layanan secara bersama-sama berpengaruh terhadap kepuasan nasabah kredit. Persamaan 2 menunjukkan Kualitas produk, kualitas layanan dan kepuasan secara bersama-sama berpengaruh terhadap loyalitas nasabah. Hasil uji F pada Tabel 4 diperoleh nilai signifikan $0,000($ sig $<\alpha=0,05)$ hasil ini memperlihatkan bahwa model mampu secara signifikan dalam menjelaskan fenomena sejauhmana variabel kualitas produk, kualitas layanan dan kepuasan secara bersama-sama berpengaruh terhadap loyalitas nasabah kredit KUR.

Hasil uji hipotesis menunjukkan hipotesis 1 nilai signifikansi $0,000<0,05$ berarti hipotesis 1 diterima. Hipotesis 2 nilai signifikansi 0,006 $<0,05$ berarti hipotesis 2 diterima. Hipotesis 3 nilai signifikansi $0,000<0,05$ berarti hipotesis 3 diterima. Hipotesis 4 nilai signifikansi $0,000<0,05$ berarti hipotesis 4 diterima. Hipotesis 5 nilai signifikansi 0,001 berarti hipotesis 5 diterima.

\section{Uji Efek Mediasi}

Pengujian efek mediasi dilakukan untuk mengetahui apakah variabel memiliki keberartian pada pengaruh langsung atau pengaruh tidak langsung. Tabel 5 menunjukkan pengaruh langsung kualitas produk terhadap loyalitas nasabah dan pengaruh tidak langsung kualitas produk terhadap loyalitas melalui kepuasan nasabah.
Berdasarkan perhitungan pada Tabel 5 dapat dijelaskan bahwa pengaruh langsung kualitas produk terhadap loyalitas sebesar 0,537 sedangkan pengaruh total kualitas produk terhadap loyalitas melalui kepuasan sebesar 0,608, maka dapat disimpulkan bahwa kualitas produk berpengaruh terhadap loyalitas nasabah melalui kepuasan nasabah.

Tabel 6 menunjukkan pengaruh langsung kualitas layanan terhadap loyalitas nasabah dan pengaruh tidak langsung kualitas layanan terhadap loyalitas melalui kepuasan nasabah.

Berdasarkan perhitungan pada Tabel 6 dapat dijelaskan bahwa pengaruh langsung kualitas layanan terhadap loyalitas sebesar 0,333 sedangkan pengaruh total kualitas layanan terhadap loyalitas melalui kepuasan nasabah sebesar 0,385, maka dapat disimpulkan bahwa kualitas layanan berpengaruh terhadap loyalitas nasabah melalui kepuasan nasabah.

\section{PEMBAHASAN}

\section{Pengaruh Kualitas Produk terhadap Kepuasan Nasabah}

Penelitian ini menunjukkan bahwa kualitas produk berpengaruh terhadap kepuasan Nasabah Kredit KUR. Hasil penelitian mendukung penelitian yang telah dilakukan oleh Munisih \& Soliha (2015) yang mengungkapkan bahwa kualitas pro-

Tabel 5. Pengaruh Kualitas Produk terhadap Loyalitas Nasabah

\begin{tabular}{lccc}
\hline \multicolumn{1}{c}{ Variabel } & $\begin{array}{c}\text { Pengaruh } \\
\text { Langsung }\end{array}$ & Pengaruh Tidak Langsung & Pengaruh Total \\
\hline $\begin{array}{l}\text { Kualitas Produk } \rightarrow \text { Kepuasan } \\
\text { Nasabah } \rightarrow \text { Loyalitas Nasabah }\end{array}$ & $\mathbf{0 , 5 3 7}$ & $0,378 \times 0,190=\mathbf{0 , 0 7 1}$ & $0,537+0,071=\mathbf{0 , 6 0 8}$ \\
\hline
\end{tabular}

Tabel 6. Pengaruh Kualitas Layanan terhadap Loyalitas Nasabah

\begin{tabular}{lccc}
\hline \multicolumn{1}{c}{ Variabel } & Pengaruh Langsung & $\begin{array}{c}\text { Pengaruh Tidak } \\
\text { Langsung }\end{array}$ & Pengaruh Total \\
\hline $\begin{array}{l}\text { Kualitas Layanan } \rightarrow \text { Kepuasan } \\
\text { Nasabah } \rightarrow \text { Loyalitas Nasabah }\end{array}$ & $\mathbf{0 , 3 3 3}$ & $0,277 \times 0,190=\mathbf{0 , 0 5 2}$ & $0,333+0,052=\mathbf{0 , 3 8 5}$ \\
\hline
\end{tabular}


duk berpengaruh positif dan signifikan terhadap kepuasan pelanggan. Penelitian yang dilakukan Lumintang \& Rotinsulu (2015) menjelaskan bahwa kualitas produk mempunyai peran dalam memasarkan suatu organisasi karena berpotensi memengaruhi persepsi dan ekspektasi nasabah tentang barang atau jasa yang ditawarkan serta pada akhirnya memengaruhi kepuasan nasabah dan loyalitas nasabah.

\section{Pengaruh Kualitas layanan terhadap Kepuasan Nasabah}

Penelitian ini menunjukkan bahwa kualitas layanan berpengaruh terhadap kepuasan Nasabah Kredit KUR. Hal ini sesuai dengan penelitian yang dilakukan oleh Agung \& Soliha (2014) dan Yuliani (2013) yang menunjukkan kualitas layanan berpengaruh positif dan signifikan terhadap kepuasan. Hasil penelitin ini juga mendukung penelitian Nursiana (2015) dan Setawan (2016) yang menunjukkan kualitas layanan berpengaruh signifikan pada kepuasan pengguna layanan mobile banking.

\section{Pengaruh Kualitas Produk terhadap Loyalitas Nasabah.}

Kualitas produk yang baik akan menimbulkan keinginan konsumen atau pelanggan untuk melakukan pembelian ulang. Kepuasan pelanggan merupakan penyebab utama timbulnya loyalitas yang tinggi. Penelitian ini menunjukkan bahwa kualitas produk berpengaruh terhadap loyalitas Nasabah Kredit KUR. Hal ini sesuai dengan penelitian Irawan \& Japarianto (2013) yang menemukan bahwa kualitas produk berpengaruh terhadap loyalitas.

\section{Pengaruh Kualitas Layanan Terhadap Loyalitas Nasabah.}

Loyalitas nasabah menggambarkan komitmen yang diberikan nasabah untuk menggunakan kembali atas jasa yang diberikan di masa yang akan datang. Gronroos (1988) mendefinisikan kualitas pelayanan sebagai hasil persepsi dari perbandingan antara harapan pelanggan dengan kinerja aktual pelayanan. Loyalitas yang tinggi dari masyarakat akan menghemat beberapa biaya bagi nasabah bank. Hasil penelitian Akbar \& Parves (2009) menunjukkan terdapat hubungan yang positif dan signifikan antara kualitas pelayanan terhadap loyalitas pelanggan. Penelitian ini menunjukkan bahwa kualitas layanan berpengaruh terhadap loyalitas nasabah Kredit KUR. Penelitian yang dilakukan Aryani \& Rosinta (2010) terdapat pengaruh yang kuat dan positif antara kualitas layanan terhadap loyalitas. Peningkatan kualitas layanan nasabah memberikan kontribusi untuk loyalitas. Demikian pula Agung \& Soliha (2014) dan Setiawan (2016) menunjukkan kualitas layanan berpengaruh signifikan pada loyalitas pengguna layanan mobile banking.

\section{Pengaruh Kepuasan Nasabah terhadap Loyalitas Nasabah.}

Kepuasan nasabah memiliki pengaruh besar dalam menciptakan loyalitas nasabah. Nasabah akan setia atau loyal terhadap suatu produk bila nasabah mendapatkan kepuasan dari produk tersebut. Untuk meningkatkan kepuasan, perusahaan perlu mengatur strategi pemasaran agar nasabah tertarik terhadap layanan yang ditawarkan.

Konsekuensi kepuasan atau ketidakpuasan nasabah sangat krusial bagi kelangsungan hidup dan daya saing perusahaan. Penelitian ini menunjukkan bahwa kepuasan berpengaruh terhadap loyalitas nasabah. Penelitian yang dilakukan oleh Hidayat (2009) menyatakan bahwa kepuasan nasabah berpengaruh positif terhadap loyalitas nasabah. Demikian pula Agung dan Soliha (2014), Munisih dan Soliha (2015), Solechah dan Soliha (2015). Setiawan (2016) juga menunjukkan kepuasan berpengaruh signifikan pada loyalitas pengguna layanan mobile banking. 


\section{SIMPULAN DAN SARAN}

\section{Simpulan}

Penelitian ini bertujuan untuk menganalisis pengaruh kulaitas produk dan kualitas layanan terhadap kepuasan dan loyalitas nasabah. Dari hasil penelitian dan pembahasan disimpulkan bahwa kualitas produk berpengaruh positif dan signifikan terhadap kepuasan nasabah, hal ini menunjukkan bahwa semakin bagus kualitas produk yang diberikan bank maka kepuasan nasabah akan semakin meningkat. Kualitas layanan berpengaruh positif dan signifikan terhadap kepuasan nasabah KUR, hal ini menunjukan bahwa semakin baik kualitas layanan yang diberikan maka kepuasan nasabah akan semakin meningkat. Kualitas produk berpengaruh positif dan signifikan terhadap loyalitas nasabah KUR, maka semakin bagus kualitas produk yang ada akan meningkatkan loyalitas nasabah. Kualitas layanan berpengaruh positif dan signifikan terhadap loyalitas nasabah KUR, maka semakin baik kualitas layanan yang diberikan akan meningkatkan loyalitas nasabah. Kepuasan nasabah berpengaruh positif dan signifikan terhadap loyalitas nasabah KUR, hal ini menunjukkan bahwa semakin puas nasabah maka akan meningkatkan loyalitasnya untuk bertransaksi di Bank BRI.

\section{Saran}

Untuk meningkatkan kepuasan dan loyalitas nasabah sebaiknya bank dapat meningkatkan kualitas produk yaitu dengan meningkatkan tingkat keamanan yang tinggi sehingga nasabah merasa aman mengambil kredit. Selain itu dengan bank sebaiknya meningkatkan kualitas produknya supaya mampu bersaing dengan produk pinjaman yang dikeluarkan bank lain. BRI juga harus meningkatkan kualitas layanan untuk meningkatkan kepuasan dan loyalitas nasabah dengan meningkatkan pelayanan, bank mampu memengaruhi harapan nasabah dengan produk pinjaman ataupun simpanan yang dikeluarkan.
Untuk penelitian yang akan datang sebaiknya dilakukan pada obyek penelitian yang berbeda dengan cakupan sampel penelitian yang lebih diperluas, baik secara geografis yaitu pada Bank BRI cabang wilayah lain dan bank lain maupun keragaman latar belakang sampel yang dilihat dari usia, pekerjaan, penghasilan, pendidikan. Cakupan sampel yang luas akan memberikan ruang yang lebih luas bagi generalisasi hasil - hasil penelitian mendatang. Bagi peneliti - peneliti lainnya, terbuka peluang untuk mengembangkan model yang lebih baik dengan memasukkan atau menambah variabelvariabel lain seperti citra bank, lokasi, dan lain-lain.

\section{DAFTAR PUSTAKA}

Agung, M.T. \& Soliha, E. 2014. Kualitas Layanan, Citra, dan Kepuasan dalam Upaya Peningkatan Loyalitas Nelayan. Prosiding Seminar Nasional dan Call for Papers, Sustainable Competitive Advantage 4. Fakultas Ekonomi dan Bisnis Universitas Jenderal Soedirman. Purwokerto.

Aidil. 2014. Analisis Pinjaman Kredit Usaha Rakyat (KUR) pada Bank BRI Kanca Tebing Tinggi Unit SEI Rampa. Jurnal Ilmiah Accounting Changes, 2(1): 26-38.

Akbar, M.M. \& Parvez. 2009. Impact of Service Quality, Trust, and Customer Satisfaction Loyalty. ABAC Journal, 29(1): 24-38.

Dimitriades. 2006. Customer Satisfaction, Loyalty, andCommitment in Service Organization, Management Research News, 29(12): 782-800.

Aryani, D. \& Rosinta, F. 2010. Pengaruh Kualitas Layanan terhadap Kepuasan Pelanggan dalam membentuk Loyalitas Pelanggan. Jurnal Ilmu Administrasi dan Organisasi, 17(2): 114-126.

Boulding, W., Kalra, A., Staelin, R., \& Zeithaml, V.A 1993. A Dynamic Process Model of Service Quality: From Expectations to Behavioral Intentions. Journal of Marketing Research, 30(1): 7.

Ghozali, I. 2011. Aplikasi Analisis Multivariate dengan Program IBM SPSS 19.Edisi 5. Semarang: Badan Penerbit Universitas Diponegoro. 
Griffin, J. 2005. Customer Loyalty, Menumbuhkan dan Mempertahankan Kesetiaan Pelanggan. Jakarta: Erlangga.

Gronroos, C. 1988. Service Quality: The Six Criteria of Good Perceived Service Quality. Review of Business, 9(3): 10-13.

Halid, A., Indriani, R., \& Suleman, D. 2014. Pengaruh Jumlah Kredit dan Suku Bunga terhadap Pendapatan Usaha Mikro di BRI Unit Kabila. Jurnal Perspektif Pembiayaan dan Pembangunan Daerah, 1(3).

Hidayat, R. 2009. Pengaruh Kualitas Layanan, Kualitas Produk dan Nilai Nasabah terhadap Kepuasan dan Loyalitas Nasabah Bank Mandiri. Jurnal Manajemen dan Kewirausahaan, 11(1): 59-72.

Irawan, D. \& Japarianto, E. 2013. Analisa Pengaruh Kualitas Produk terhadap Loyalitas Melalui Kepuasan sebagai Variabel Intervening pada Pelanggan Restoran Por Kee Surabaya. Jurnal Manajemen Pemasaran, 1(2): 1-8.

Kotler, P. \& Amstrong, G. 2012. Principles of Marketing, Global Edition. 14 ${ }^{\text {th }}$ Edition. Pearson Education.

Kotler, P. \& Keller, K.L. 2009. Marketing Management.13 ${ }^{\text {th }}$ Edition. United States of America: Pearson.

Kotler, P. \& Keller, K.L. 2013. Marketing Management. $14^{\text {th }}$ Edition. United States of America: Pearson.

Liu, T. \& Wu, L. 2007. Customer Retention and Crossbuying in the Banking Industry: An Integration of Service Attributes, Satisfaction and Trust. Journal of Financial Services Marketing, 12(2): 132-145.

Lumintang, G. \& Rotinsulu, J.J. 2015. Analisis Kualitas Produk dan Kualitas Layanan terhadap Kepuasan Pelanggan pada Holland Bakery Boulevard Manado. Jurnal EMBA, 3(1): 1291-1302.

Munisih, S. \& Soliha, E. 2015. Pengaruh Kualitas Produk terhadap Nilai Pelanggan dan Kepuasan pelanggan dan Dampaknya pada Loyalitas Pelanggan Apotek Dela Semarang. Prosiding Semi- nar Nasional \& Call for Paper, Kinerja Perbankan, Bisnis dan Ekonomi Indonesia Menghadapi AEC 2015. Fakultas Ekonomika dan Bisnis, Universitas Stikubank. Semarang.

Nursiana, A. 2015. Pengaruh Internet Banking, Kualitas Layanan, Reputasi Produk, Lokasi terhadap Loyalitas Nasabah dengan Intermediasi Kepuasan Nasabah. Jurnal Keuangan dan Perbankan, 19(3): 450-462.

Parasuraman, A., Zeithaml, V.A., \& Berry, LL. 1985. A Conceptual Model of Service Quality and Implications for Future Research. The Journal of Marketing, 49: 41-50.

Prawirosentono, S. 2004. Filosofi Baru Tentang Manajemen Mutu Terpadu: Total Quality Manajement Abad 21, Studi Kasus dan Analisis, Jakarta: Bumi Aksara.

Setiawan, H. 2016. Pengaruh Kualitas Layanan, Persepsi Nilai dan Kepercayaan terhadap Kepuasan dan Loyalitas Pengguna Layanan Mobile Banking. Jurnal Keuangan dan Perbankan, 20(3): 518-528.

Solechah \& Soliha, E. 2015. Pengaruh Citra dan kepercayaan terhadap Nilai Pelanggan dan Dampaknya pada Kepuasan serta Loyalitas Nasabah, Proceeding 4th Economic \& Business Research Festival, Business Dynamic Toward Indonesia Economic Revival. Fakultas Ekonomika dan Bisnis Universitas Kristen Satya Wacana. Salatiga.

Sumadi \& Soliha, E. 2015. The Effect of Bank Image and Trust on Loyalty Mediated by Consumer Satisfaction. Jurnal Dinamika Manajemen, 6(2): 121-132.

Taylor, S.A. \& Baker, T.L. 1994. An Assessment of the Relationship between Service Quality and Customer Satisfaction in the Formation of Consumers' Purchase Intentions. Journal of Retailing, 70(2): 163-178.

Yulianti, F. 2013. Pengaruh Kualitas Pelayanan terhadap Kepuasan Nasabah Tabungan pada Bank Panin TBK KCP A.Yani Banjarmasin. Jurnal Spread, 3(2): $87-100$. 